Journal of Southeast Asian

\title{
To Know a Bāthā: Family Language Socialization among Buddhist Immigrants from Myanmar in New York City
}

Chu M. Paing

University of Colorado Boulder, chu.paing@colorado.edu

Follow this and additional works at: https://docs.lib.purdue.edu/jsaaea

Part of the Bilingual, Multilingual, and Multicultural Education Commons

\section{Recommended Citation}

Paing, Chu M. (2018) "To Know a Bāthā: Family Language Socialization among Buddhist Immigrants from Myanmar in New York City," Journal of Southeast Asian American Education and Advancement: Vol. 13 : Iss. 1, Article 10.

DOI: $10.7771 / 2153-8999.1169$

Available at: https://docs.lib.purdue.edu/jsaaea/vol13/iss1/10

This document has been made available through Purdue e-Pubs, a service of the Purdue University Libraries. Please contact epubs@purdue.edu for additional information.

This is an Open Access journal. This means that it uses a funding model that does not charge readers or their institutions for access. Readers may freely read, download, copy, distribute, print, search, or link to the full texts of articles. This journal is covered under the CC BY-NC-ND license. 


\section{To Know a Bāthā: Family Language Socialization among Buddhist Immigrants from Myanmar in New York City}

\section{Cover Page Footnote}

My greatest gratitude goes to my mentor Prof. Miki Makihara for her thought-provoking comments. I am also thankful to Prof. Karen Strassler, Prof. Juan Rodriguez, Prof. Thomas Ort, and Prof. Barbara Simerka for their support throughout this study. This paper also benefited from insightful comments and suggestions from anonymous reviewers. Any other error in this paper remains mine alone. This study is a part of my Honors thesis funded by the Honors in the Social Sciences program and Linakis Research Scholarship at Queens College at the City University of New York and the Pipeline program at the Graduate Center at the City University of New York. 


\title{
JSAAEA Journal of Southeast Asían American
Education and Advancement
}

Vol. 13 Iss. 1 (2018)

WwW.JSAAEA.org

\section{To Know a Bāthā: Family Language Socialization among Buddhist Immigrants from Myanmar in New York City}

\author{
Chu M. Paing \\ University of Colorado Boulder
}

\begin{abstract}
While there is a rising number of research studies on heritage language maintenance among East Asian immigrants, there have been very few studies on Southeast Asian minority heritage language maintenance. The purpose of this paper is to shed light on the practices and ideologies towards heritage language maintenance in two Buddhist immigrant families from Myanmar residing in New York City. This paper approaches the topic of heritage language maintenance by employing Elinor Ochs and Bambi Schieffelin's (1984) theoretical framework on language socialization-socializing U.S. born Burmese children to become competent members of both their heritage and American societies. The findings suggest that the socio-semantically ambiguous concept bāthā in Burmese referencing both language and religion leads to the prioritization of religious socialization over language socialization in the process of heritage language maintenance. Although the former could compliment the latter, both families seemed to be satisfied by the achievement of the former. By doing so, the participants in this study however achieve in successfully compromising between full assimilation to mainstream American society as a minority immigrant community and maintaining their heritage roots, even if not linguistically.
\end{abstract}

Keywords: Burmese immigrants, language and religion, heritage language maintenance, family language socialization, storytelling, language ideology, family language policy, Bama, Burmese-Chinese, Burmese and Buddhism.

\footnotetext{
(a)

SDRERIIGHISRESERNEDR Readers are free to copy, display, and distribute this article, as long as the work is attributed to the author(s) and the Journal of Southeast Asian American Education \& Advancement, it is distributed for non-commercial purposes only, and no alteration or transformation is made in the work. More details of this Creative Commons license are available at http://creativecommons.org/licenses/by-nc-nd/3.0/. All other uses must be approved by the author(s) or JSAAEA. Journal of Southeast Asian American Education \& Advancement, Vol. 13. Iss. 1. (2018) ISSN: 2153-8999
} 


\section{Introduction: Born and Raised in a Burmese Home}

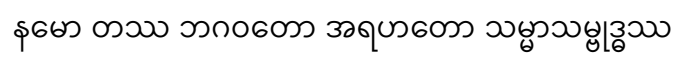

Namaw tathà bagawataw ayahàtaw thanmāthanboatdathà. ${ }^{1}$

I pay homage to the great Buddha and his brightest intelligence, knowledge, and honors with all my mind, body, and soul. ${ }^{2}$

It is quarter past eight at night. On the floor in the prayer room area of her two-bedroom basement apartment in Jackson Heights, sits cross-legged Daw Khin $\mathrm{Kyi}^{3}$ and her 9-year-old younger nephew, Maung Htain Lin, ${ }^{4}$ with their hands folded around their chests. In front of them is a small table on which a seven-inch tall Buddha statue, adorned with gold paint, in the cross-legged posture, lies. On both sides of the statue are ceramics pots, filled with freshly-washed bright yellow chrysanthemums or gandamas - as Burmese calls it inside. In front of the statue are three small glasses of water. Twinkling Christmas string lights decoratively wrap around the table and complete the setting of the phayasin..$^{5}$ There are no other sounds except the chanting of above Buddhist prayer by Daw Khin Kyi and Maung Htain Lin's repeating after her. Her sister, Daw Khin Thi, has left for her night shift at the post office; both of Daw Khin Kyi and Daw Khin Thi's husbands are also out working. Her older nephew, Maung Kyaw Lin, is playing a game on his computer in the living room, just a few inches away from the prayer room area. While Daw Khin Kyi, with her eyes closed and her posture stable, seems to be deeply immersed in the sound and the act of chanting, Maung Htain Lin seems restless, often glancing into the living room, with his toes wriggling, and his body moving back and forth, as if he cannot wait to join his elder brother after the prayer. And with a full body prostration towards the Buddha statue at the end of the prayer, a day has gone by at Daw Khin Kyi's home in Jackson Heights, New York City. ${ }^{6}$

Daw Khin Kyi occasionally leads the "easier" or "more routinely" chants just as the excerpt above, and asks her younger nephew, who was born and raised in New York City, to repeat them after her. The word "easier" indicates the typical Buddhist chants done daily by Burmese Buddhists as described above. They are usually done twice daily — in the morning and at night - by devout Buddhists. Public schools in Myanmar also reinforce these "easier" chants in their everyday school routine, usually after singing the Burmese national anthem, and before the first period of a school day. In some occasions, a fifteen-minute meditation session follows before the school day starts. The "harder" or "more difficult" chants are elaborate and longer Pali ${ }^{7}$ chants, usually done by the monks or the adults. Both "easier" and "harder" prayers are in Pali words, however, written in Burmese alphabets just as the excerpt above, reproducing the closest phonemes of the original Pali prayers. The monks usually narrate the loose translations - as described above with the excerptof the prayers in their sermons. The above prayer is usually chanted at the beginning of a session. Both adults and children in a Burmese Buddhist community are expected to learn these "easier" chants by heart; but not necessarily the more elaborate chants. The ability to recite the latter is a sign of piety in the Burmese Buddhist community. There are however very few who understand word-to-word Burmese to Pali translations of those prayers, except the monks who are trained to read and write in Pali. Daw Khin Kyi herself, in this setting, knows of only the loose translation of the prayer that she was leading Maung Htain Lin to repeat after her. As a self-identified devout Buddhist, Daw Khin Kyi feels an urge to help her nephew who was born and raised in New York City to learn the prayers, at least the "easier" chants. These prayers are not necessarily in colloquial Burmese. However, first generation Burmese caretakers like Daw Khin Kyi believes that 
Buddhism is the only mode to culturally and linguistically socialize their U.S. born children into both the Burmese immigrant community and a larger Burmese Buddhist community back in Myanmar.

New York City has been home for millions of immigrants from all over the world. The borough of Queens has been identified as the most linguistically diverse neighborhood according to the project led by the Endangered Language Alliance in New York City (Solinit \& JellyScharpio, 2016). Along with the hope to seek better economic, sociopolitical, and education prosperity, these immigrants being their cultural identities through the languages they speak, the food that they eat, and the cultural practices - be it religious, as seen above in the nightly prayer session in a Burmese immigrant's home in Jackson Heights, within their households or in their communities. At the same time, they also face the challenges to at least partially - if not totallyassimilate into the mainstream culture and language through generations. Overtime, they tend to lose their heritage languages. Fishman (1970) describes this phenomenon as "natural intergenerational transmission." The second generation tends to be bilingual in both heritage language and dominant language; by the third generation who becomes monolingual in dominant language, the loss of heritage language is inevitable. It is worth studying the patterns of heritage language maintenance, and the reason why language shift may be fastened or delayed in relation to the speakers' language socialization, language ideologies, practices, and their individual and collective identities as immigrants in this new home country. A number of linguistic anthropologists and sociolinguists have been exploring these patterns in heritage language and language shift in Korean, Chinese, Japanese, Puerto Rican, Hmong, Khmer, Indian, and other immigrant communities in the United States. (see Kang, 2012; Karamuwa \& Goza, 2009; Lao \& Lee, 2006; Leung, 2012; Lee, 2006; Shiow-Houy \& Wiseman, 2000; Sridhar, 1988; Yang, 2008; Zhang, 2009; Zentalla, 1997). This paper contributes to the scholarly discussion on heritage language maintenance and language shift among immigrants in the U.S through an ethnographic case study on two Burmese immigrant families in New York City. I approached heritage language maintenance through Ochs and Schieffelin's (1984) theoretical framework on language socialization. This paper concerns the following questions: How do Burmese caretakers socialize with their U.S. born children through the language in their daily encounters? What are their language ideologies and practices towards becoming a competent Burmese across immigrant generations? Here, I employ Irvine's (1989) definition of language ideology as "the cultural system of ideas about social and linguistic relationship, together with their loading of moral and political interests" (p. 255).

\section{Literature Review}

Linguistic anthropologists and sociolinguists have been exploring the topic of heritage language maintenance among various immigrant groups from the perspectives of parent-child interaction, development of family language policies, educational support on heritage languages, and so forth. Kang (2012) highlights the importance of the role of a parent in heritage language maintenance since parents in her study strongly reinforce family language policy to speak Korean at home. Family language policy is defined as "explicit and implicit planning in relation to acquisition of language skills in home settings, in contrast to those espoused by the state or other organizations" (King et al., 2008). On the other hand, Yang (2008) witnesses the struggle of his Hmong participants in attempting to maintain Hmong across generation. Second generation Hmong participants view Hmong as a disadvantageous language in the United States; they claim to 
encounter racism while speaking Hmong outside of the household such as at job interviews. This stigma of speaking their heritage language seems to hinder the process of heritage language maintenance among minority immigrant communities like the Hmong although they wish otherwise.

Using "Individual Network of Linguistic Context (INLC)" framework, Zhang (2009) looks at interpersonal contact, educational support, and contact through media in Chinese (Mandarin) heritage language maintenance with three focal $1.5^{8}$ and second-generation children in the Greater Philadelphia area. His findings show that formal education and media support such as TV and music in addition to parental involvement greatly accelerate Mandarin language maintenance among his U.S. born Chinese participants. However, the sociopolitical status of a language - such that Mandarin and Korean (Kang, 2012), are more economically advantageous compared to Hmong in Yang (2008)'s study - plays a factor in maintaining the heritage languages across the immigrant generations in the United States. This factor also seems prominent in other minority immigrant languages.

Setsue (2000) explores how Japanese immigrant families in a small town succeed in heritage language maintenance even when their ethnolinguisitc vitality (Giles \& Johnson, 1987) was low. The term refers to a group's ability to survive as a distinctive collective entity in an intergroup setting. Ethnolinguistic vitality is also a major factor in maintenance, loss, promotion, and reviving a language. Although Japanese can be considered a socioeconomically advantageous language, the lack of formal support for heritage language maintenance in the participants' town threatens its ethnolinguistic vitality. Since the participants in this study intend to return to Japan, they make efforts to resist language shift such as establishing a Japanese language school on weekends. Parental and communal desire to help maintain heritage language maintenance plays an important role even when its ethnolinguistic vitality is being challenged. This study is also an example in which the status and emotions of (im)migration as temporary or permanent influences ideologies and practices towards heritage language maintenance.

In a study with $1.75^{9}$ generation Khmer immigrants, Lao and Lee (2009) find that due to language barriers of their caretakers at home, these participants have no choice but to speak Khmer within household. Most of them are the first in the family to attend school and learn English. Their parents or caretakers rely on them to carry out daily social action by interpreting and translating for them; by becoming language brokers, "children play linguistic intermediary role between nonEnglish speaking parents and English speakers in the United States" (Buriel, 2014). Regardless of language brokering, which helps lubricate the process of heritage language maintenance among their participants, Lao and Lee (2009) predict the language shift from Khmer to English by third generation due to their lack of Khmer literacy. In another study with a Khmer refugee community in the Boston area, Smith-Hefner (1990) finds that a strong belief in "reincarnation or transmigration of the soul," influences her Buddhist Khmer participants' family language policies. Her participants believe that "one's present state is determined in part by one's behavior in the past" (p. 263). A mother in this study goes as far as to claim that her child's lack of linguistic proficiency in English and Khmer is due to the "bad acts" he performed in previous life. These studies show various language ideologies and approaches to heritage language maintenance among different immigrant communities. Parental involvement, family language policy, family language socialization, socioeconomic status of a target language, ethnolinguistic vitality of a language, and other cultural factors contributing to language ideologies are among the reasons behind accelerating and hindering the process of heritage language maintenance. 
Ochs and Schieffelin (1984) develop theoretical framework on language socialization to observe the process of language acquisition foregrounding the importance of social and cultural practices in a speech community. Unlike language acquisition, the focus of language socialization "neither rests on less experienced persons as acquirers nor more experienced persons as input but rather on socially and culturally organized interactions that conjoin less and more experienced persons in the structuring of knowledge, emotion, and social action" (Ochs, 2000). Acquiring a language is not merely being able to speak the language, but also being able to create socially and culturally meaningful relationships among the members of the society. Through these relationships, individuals become the competent members of that society. Language becomes a device to achieve this process of becoming a competent member of the society, "by acquiring knowledge of its functions, social distribution, and interpretations in and across socially-defined situations" (Ochs \& Schieffelin, 1984, p. 277). Ways in which caretakers carry out language socialization differ as those socially-defined situations also vary from one society to another.

Although primary works on language socialization generously focus on monolingual communities and first language acquisition, it could also be applied to bilingualism and second language acquisition as in heritage language acquisition. Schieffelin (1994) discusses the language socialization input in multilingual and multidialectal households. In her pilot project with a Haitian family in New York City, she looks at code-switching as a pattern of language socialization in raising bilingual children in both Creole and English. I intend to explore similar language socialization patterns such as the role of language input among U.S. born Burmese children, who are expected to be raised in bilingual households. Considering the importance of adults' participation in child language acquisition as discussed in various language socialization works (see Baquedano-López \& Garrett, 2002; Baquedano-López \& Kattan, 2007; Crago, 1993; Duff, 2010; Garrett, 2005; Makihara, 2005; Ochs \& Schieffelin, 1984; Paugh, 2005), this paper pays attention to adult participants' language ideologies, how they define their society-be it Burmese or American or both-and their ways of developing children as competent members of their defined society or societies.

\section{Method}

The findings presented in this paper are extracted from a longer ethnographic research I conducted in 2016 and 2017. As a Buddhist Burmese (Bama-ethnic) immigrant, I am a member of the community of practice that I describe in this paper. Following my arrival in New York City in 2012, I rented a small bedroom with shared kitchen and bathroom in a house owned by a Burmese family in Jackson Heights. By 2016, I had moved away from Jackson Heights, yet remained in contact with the family and continued to attend the community events. I later worked as a tutor for one of the family's U.S. born sons. My then decision to live with the Burmese family was solely due to my own survival as a recent immigrant in the United States. (i.e., the more affordable rent and the safety I felt from living with a Burmese family as a 19-year-old recent immigrant). Although I did not initially intend to do a research on Burmese immigrants, the years I spent living with the Burmese family and my experiences as a member of this community of practice greatly contributed to my research. The family I lived with became one of the focal participant-families; the young boy I tutored became one of the focal child-participants in my research. I also recruited another immigrant family through the introduction of the family with whom I lived. The details of the participants are presented in the Participants section. 
As mentioned above, it was not until in the summer of 2016 I began formally conducting the research. From the summer of 2016 until the summer of 2017, I collected ethnographic data via interviews and participant-observations from two families. Some retrospective recollections also helped me with "thickly describing" (Geertz, 1973) my participants' daily routines. For instance, the opening vignette of this paper was reconstructed from my memories of living with the family prior to the formal data collection. I used the interview questions as prompts to initiate conversations rather than to collect survey-like data. The questions included, but not limited to, whether they speak Burmese at home and what they think about speaking it. Each conversation lasted from 30 minutes to 2 hours. I audio-recorded these conversations with the consents of my participants. I also partook in daily activities of my participants, usually the women's and the children's. I would help around the kitchen or play with the children while the women ran other errands around the house. I also joined the adult-participants in trips to the children's after-school programs in other neighborhoods of New York City. The data from this research is not to be applicable for all immigrants — of different faiths, ethnic and linguistic backgrounds - from Myanmar in the United States. My intention is to gain and present a detailed understanding of the particularities of two Buddhist immigrant families from Myanmar living in Jackson Heights, and the chosen methods (ethnographic interviews and participant-observations) assisted me to precisely carry out this intention.

\section{Field Site: Jackson Heights}

The bell for the top floor in an apartment building at the corner of $75^{\text {th }}$ street and Broadway in Jackson Heights used to be $^{10}$ the secret ring for Burmese immigrants across boroughs in New York City. You ring the bell, and a lady, who may resemble as Thai or Indonesian, would come out to the balcony, and asks in Burmese language if you need anything. Once you replied in Burmese, she would throw down a key to the front door to you. This is a typical way of selling and buying homemade Burmese meals to and from immigrants in Jackson Heights.

Jackson Heights is one of the first neighborhoods on which immigrants from Myanmar set their eyes and created a center of their social circle upon their arrivals in New York City. Its convenient location to Manhattan and resemblance of culture and food of their Himalayan neighbors provide them with the most-suitable place to transition and resettle in this new city. Nowadays, Jackson Heights is not only a place where the Burmese socialization takes place for immigrants in New York City, but also the first stop in New York City for new immigrants from Myanmar. Indeed, my first encounter to New York City was Jackson Heights aside from landing in John F. Kennedy airport.

The most well-known Burmese Buddhist monastery in New York City, formally named Wi Thuda Yone Dhamma Yan Thi ${ }^{11}$ and popular among Buddhist immigrants as Thone Par Kyaung (lit: Three-Monk monastery), is also located on the border of Jackson Heights and Elmhurst, a few blocks away from 74 street-Jackson Heights subway station. This monastery has become not only a religious venue, but also a space for Buddhist immigrants from Myanmar to socialize and recreate a Burmese Buddhist way of life. Older Buddhist immigrants, such as the parents who were brought to the United States by their children, gather from dawn to dusk at Thone Par Kyaung for a chat while sipping Burmese tea. U.S. born Burmese children are introduced to the Buddhist way of living through social and cultural activities like monthly religious events held at Thone Par Kyaung. Immigrants from Myanmar have created a physical place of their home in Jackson Heights, recalling their memories of an emotional space from Myanmar. 
A couple of so-called "underground" Burmese chefs, who make and sell homemade Burman takeout dishes exclusively for immigrants from Myanmar in New York City also resides in Jackson Heights. In the spring of 2017, I saw an advertisement about the opening of a Burmese grocery store named "Dò Myanma (lit: Our Myanmar)" on $37^{\text {th }}$ avenue in Jackson Heights in a closed Facebook group New York City Burmese Community ${ }^{12}$; and a few months later, another advertisement about a hair salon opened by a Burmese lady who recently moved from Maryland to New York City. The presence of immigrants from Myanmar have been booming in Jackson Heights in recent years. Although their presence still may not be visible, many immigrants from Myanmar in New York City have been recreating a home away from home in Jackson Heights. As a member of this community of practice, there was no better field site than Jackson Heights to carry out an ethnographic research on Buddhist immigrants from Myanmar.

\section{Participants}

Daw Khin Kyi and Her Nephew Maung Htain Lin. The first participant family resides a few blocks away from Thone Par Kyaung monastery and Jackson Heights subway station. About twenty-five years ago, 19-year-old $\mathrm{Ma}^{13} \mathrm{Khin} \mathrm{Thi}^{14}$ arrived alone in New York City from Pathein, the fourth largest port city in Irrawaddy region in Myanmar, as one of the winners of the U.S Diversity Visa Lottery. Both of her parents were second generation Chinese immigrants in Myanmar, and therefore, she was considered a Bama-Chinese (tayoat) in a city mostly populated with Burman-ethnic like Pathein.

Chinese immigrants (or) tayoat - as widely referred to by Burmese-who settled in Myanmar during $18^{\text {th }}$ and $19^{\text {th }}$ century, came from various regions of China. Their primary languages $^{15}$ and cultures differ based on their regional roots in China. Additional Chinese immigrants from British colonial ports such as Penang, Singapore, and Melaka straits also resettled in Myanmar during $19^{\text {th }}$ and $20^{\text {th }}$ century. These Chinese immigrants in Myanmar initially were successful in maintaining their cultural and linguistic heritage in Myanmar-through language schools, and Chinese language newspapers. They also restricted interracial marriages with Burmese and reinforce marriages only to other Chinese immigrants of the same heritage descents. However, the military regime's attempt to reunite the country in 1960s hindered Chinese heritage maintenance in Myanmar (Charney, 2002). "Two generation of Chinese immigrants in Myanmar had not had formal instruction in Mandarin, and relied chiefly on Burmese language, and a combination of Burmese and one of several traditional dialects (Hokkien, Gungdong, etc)" (Charney, 2002, p. 34). Furthermore, Burma Citizenship Law in 1982 did not grant citizenship to long-settled Chinese immigrants and their descendants in Myanmar and treated them as "secondclass citizens." Since most of them were unable to obtain jobs without citizenship status, many Chinese immigrants from Myanmar migrated to third countries including the United States, Australia, and Taiwan (Charney, 2002). Those who decided to stay behind were later granted Burmese citizenship, and became socially, religiously, and linguistically integrated into their respective host cities in Myanmar. Most of them are Buddhists and speak Burmese. Growing up in this era, neither Ma Khin Thi's parents nor she and her siblings speak Mandarin or their Chinese regional dialect anymore; they speak Burmese and had successfully adapted to mainstream Burmese culture (i.e., the culture of ethnic-majority Burman). Burman culture is also the one that they wish to maintain after migrating to the United States.

Regardless of their assimilation, the Burmese-Chinese had been subjected to an ethnic identity in Myanmar, just as other indigenous groups have; that is tayoat/Chinese (or) bama- 
tayaot/Burmese-Chinese although many of them choose to self-identify themselves as Bama. Due to the centuries-long political narratives towards Chinese immigrants as foreigners and outsiders, the term tayoat carries negative bias towards Chinese immigrants in Myanmar. When asked of an ethnic identity, many Chinese descendants in Myanmar give an answer, Burmese or BamaChinese. Although they had assimilated into mainstream culture, their physical appearance such as lighter skin, soft and straight hair, and mono-eyelid, compared to darker skinned, and brownish haired Burmans, constantly labels them as non-indigenous and outsiders in Myanmar. Regardless of their self-identifications, their claimed identity as Burmese is still being contested by those in Myanmar, and in Burmese diasporas. In order not to perpetuate such biases, I opted to use the term Bama-Chinese to refer to my Burmese-Chinese participants hereafter.

Upon her arrival in New York City as a young immigrant, Ma Khin Thi chose to stay with the rest of Bama immigrants in Jackson Heights: a place where she continued to stay even after twenty-five years later. By tenth years since she arrived, Daw ${ }^{16}$ Khin Thi had successfully assimilated into American society. She had become an American citizen, married a Bama-Chinese man from Myanmar, whom she met in Queens, New York City, bought a house in Jackson Heights, and brought her mother and her eldest sister, Daw Khin ${ }^{17}$ Kyi, to New York City as permanent residents. By the time I met her, she had gained a senior employee status at the U.S. post office after working there for past ten years. With a smile on her face, she proudly said, "That was the house I first stayed at when I came here!" pointing to the house next to hers. A few years ago, her mother passed away in New York City, and now she lives with her husband and her two sons (12year-old Maung ${ }^{18}$ Kyaw Lin and 9-year-old Maung Htain Lin) who were both born and raised in New York City, and her eldest sister Daw Khin Kyi. Daw Khin Kyi also married a Bama-Chinese man whom she met in New York City, and he moved into Daw Khin Thi and Daw Khin Kyi's home. Daw Khin Kyi and her husband do not have children of their own.

Daw Khin Thi, together with her sister, Daw Khin Kyi, decided to expand their income by transforming the upstairs of their house into hostel-like apartments for new immigrants. I stayed in one of those rooms on the first floor of their house during my early years in the United States. There was a total of five rooms, occupied by immigrants from Myanmar, two bathrooms, and one kitchen on my floor. Their family also works as a courier, who travels and brings packages to and from the United States, and Myanmar, for other Burmese immigrants or immigrant-alike. They are also close with Thone Par Kyaung monastery. Since Daw Khin Thi works night shifts at the U.S. Postal Services, and sleeps during the daytime, Daw Khin Kyi is a key figure in managing any household affairs such as taking care of her nephews, sending them and picking them up from schools, cooking, cleaning, and dealing with courier business as well as with the tenants in their house.

Due to the amount of time that Daw Khin Kyi spent with her nephews, I decided to observe language socialization between Daw Khin Kyi and her younger nephew, Maung Htain Lin in this family. Although I initially expected to observe both Maung Htain Lin and her elder brother Maung Kyaw Lin, Maung Kyaw Lin expressed his desire not to be a part of my research; I therefore excluded him in my primary observation.

Daw Hnin Si And Her Daughter Ma Mya Lay. Daw Hnin Si arrived in New York City about thirteen years ago with her then five-year-old elder daughter, Ma Moe Lay. Five years earlier, her husband U Myint Swe had arrived in the States on a student visa. Upon arrival, Daw Hnin Si worked as an office assistant at a jewelry company in midtown, Manhattan; in fact, jewelry companies around $46^{\text {th }}$ Street, Manhattan are known to be populated with immigrant workers from 
Myanmar. Being surrounded by other Burmese-speaking co-workers, Daw Hnin Si did not have trouble transitioning her life from Myanmar to New York City. After five years, she became pregnant with her second daughter, Ma Mya Lay, and it was then she decided to quit her job and became a full-time stay-at-home mother. She has also become one of the "underground" Burmese chefs; she regularly cooks for the monks at Thone Par Kyaung monastery, as well as for any immigrants from Myanmar who makes specific food orders from her. Living only a few blocks away from Daw Khin Kyi and Daw Khin Thi, Daw Hnin Si is also a close friend of them, and remains to have a "closely-knitted" (Zentella, 1997) Burman social circle in her daily life in New York City.

Often, Daw Hnin Si reminiscences about her college student life back home in Yangon University, where she first met her husband, who was an engineering student at that time. Being born and raised in Yangon, the former capital city of Myanmar, Daw Hnin Si portrays herself as modern and sophisticated. U Myint Swe was born and raised in Thandwe, Rakhine State (or known as Arakanese in precolonial period), the western part of Myanmar, where an ethnic language, Rakhine or Arakanese, is spoken. Although Rakhine is regarded as a different language due to the government's official recognition of the people and the state of Rakhine as one of the major ethnicities, Rakhine is linguistically a dialect of Burmese with a different phonological pattern. While speakers of both languages (or dialects) can understand each other, Rakhine people are bidialectal and ethnic-Bama are monolingual and monodialectal due to the military regime's century-long reinforcement to officialize Burmese as the national language. Regardless of Rakhine being his first language, U Myint Swe does not speak Rakhine in his household. He uses Burmese to communicate with his wife and other Burmese immigrants, and English to communicate with her daughters. In this family, I focused on interaction between Daw Hnin Si and Ma Mya Lay.

Language Proficiencies Both of my child participants have listening ability in Burmese. Maung Htain Lin was ${ }^{19}$ able to speak to Daw Khin Kyi and me in Burmese with an American accent. ${ }^{20}$ Ma Mya Lay, on the other hand, was eager to reply to Daw Hnin Si and me in English although she seemed to understand Burmese. She uttered only a few Burmese words throughout my observation period. She used Burmese to describe the name of the Burmese dishes. Refer to Figure 1 for the participants' language proficiencies, and the linguistic dynamics between each other during the period of my research. Burmese language proficiencies of child-participants, and English proficiencies of adult participants were loosely made based on my personal judgments as a native Burmese speaker.

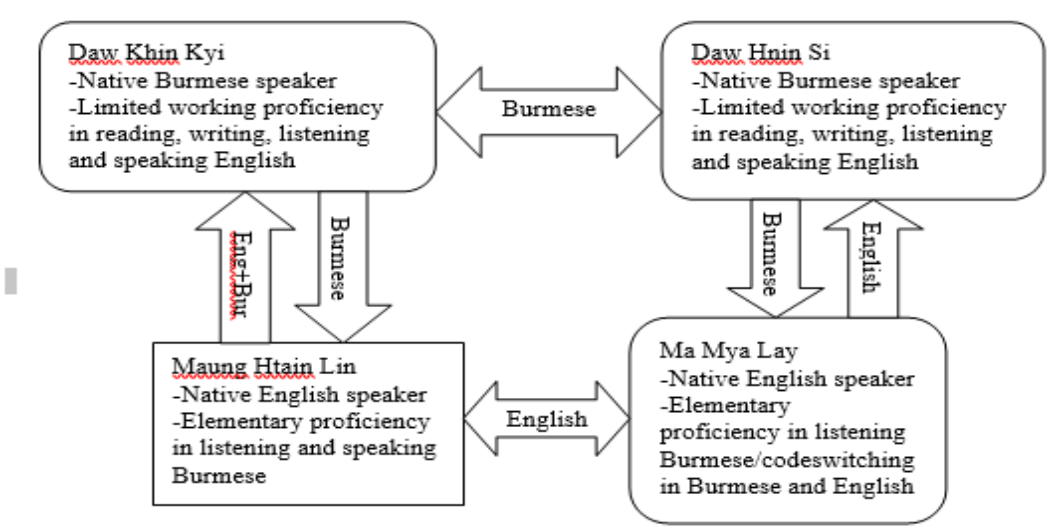

Figure 1. Language Proficiencies and Language Interaction between Participants. 
DAw ThuzAR. Daw Thuzar is a first-generation Burmese immigrant and a practicing pediatrician in Brooklyn. She arrived in New York City twenty-five years ago. She lives with her mother and three children, who were all born and raised in New York City. Downstairs in her house was used for clinic during the daytime, and upstairs in her house was used for religious retreats or meditation camps for Burmese immigrants across the United States. Although she was not the family pediatrician for my child-participants, she played a vital role among Burmese immigrant families across boroughs in New York City in terms of providing Buddhist lessons for U.S. born children. Often, she invited the renowned monks from Myanmar, and held a week or ten-day long Buddhist retreat at her place. On weekends, she provided lessons on Abhi Dhamma, the ancient Buddhist texts-usually written in Pali, consisting of Buddha sutras for children. Both Daw Khin Kyi and Daw Hnin Si sporadically sent Maung Htain Lin and Ma Mya Lay to those lessons. I came to know Daw Thuzar through my participants and conducted an ethnographic interview with her about the lessons. However, I was unable to observe these lessons or retreats since she took a break from offering them due to her workload as a pediatrician during my observation period.

\section{Analysis}

\section{Mirroring Bāthātaya and Bāthāzaga}

In Burmese, the word $b \bar{a} t h \bar{a}$, believed to be borrowed from Pali or Sanskrit, could mean religion or language. Burmese language has loanwords from classic Indian languages such as Sanskrit and Pali. "Sanskrit and Pali words and phrases are abundant in Old Burmese (OB) inscriptions. Especially religious and ceremonial terminology is mostly of Indian origin, but also a number of everyday lexical items are Pali (or, less commonly, Sanskrit) loans" (Jenny, 2015, p. 4). The loanword $b \bar{a} t h \bar{a}$ was historically used to indicate the acquisition or the knowledge of literacy and moral education through Buddhism. Religion through monastic education was the only source of not only social and moral but also literacy knowledge in ancient Myanmar's Kingdoms. ${ }^{21}$ However, this is not the case in the cities of modern-day Myanmar. Public schools now offer Western education such as science and applied sciences in addition to traditional social and moral education. Therefore, the breadth of the meaning of the term bāth $\bar{a}$ became inclusive of the acquisition or the knowledge of literacy in both religious and non-religious education. For instance, the term $b \bar{a} t h \bar{a}$ is attached to the names of each subject taught at public schools in Myanmar-as in myanma bāthāa (lit: Burmese subject) and thatepan bätha (lit: science subject) - to suggest the acquisition or the knowledge of that subject. In some occasions, to avoid the ambiguity, Burmese, an agglutinative language, allows the attachments of additional suffixes and morphemes. A morpheme taya, by itself, means justice, fairness, or moral principles. When it attaches to bāthā, and bäthätaya (lit: the acquisition or knowledge of justice, fairness or moral principles) and exclusively refers to religion. Zaga, on the other hands, means "speech" or "utterance" and bāthāzaga (lit: the acquisition of language) only refers to language. However, in daily conversations, Burmese speakers use the back-clipped version, $b \bar{a} t h \bar{a}$, to refer to either religion or language; the context of the conversation helps interlocutors determine the intended meaning of the word. 


\section{Family Bāthā Socialization}

The concept of the term $b \bar{a} t h \bar{a}$ referencing both religion and language greatly impacts language ideologies towards Burmese among my adult participants. As a self-identified pious Buddhist, Daw Khin Kyi was dedicated to her daily religious rituals such as evening meditation sessions at home, morning prayer recitals, and local religious celebration at Thone Par Kyoung monastery. She defined piety as the quality of a good human being. Attending to those rituals were more important to her than any other household activities. In one occasion, I called her home for a chat, and her sister asked me to return the call a few hours later since Daw Khin Kyi was in a meditation session. Despite her socially-assigned ethnic identity back in Myanmar as Bama-Chinese (or) a descendent of China, Daw Khin Kyi self-identified as Bama; she indexed her closeness to Bama through her devotion to Buddhism. Her physical look as Chinese occasionally led to an inadvertent exclusion from other Burmese immigrants. She laughingly remarked that other immigrants from Myanmar would not recognize her as a Burmese at a first glance due to her Chinese appearance whereas Chinese immigrants would begin speaking to her in Mandarin in New York City. When asked if she also speaks Mandarin, Daw Khin Kyi strongly rejected, "No! No! I don't speak any Chinese. My parents [who were second generation Chinese immigrants in Myanmar] don't speak Chinese either." Also, she did not intend to teach Mandarin to her U.S. born nephews. Language, more importantly, speaking only Burmese, was a primary tool for Daw Khin Kyi to gain recognition from other immigrants from Myanmar in the United States. In addition to being recognized as somebody from Myanmar by speaking Burmese, Daw Khin Kyi tried to assert her Bama identity by being a Buddhist; not merely, but devotedly. This sense of belonging to Myanmar through Buddhism also impacted her language ideology towards passing Burmese onto her U.S. born nephews. Text 1 shows her language ideology that was interlaced with Buddhism.

Text 1. Daw Khin Kyi's Ideologies towards Burmese Language and Buddhism (Conversation record on 7 May 2016) $)^{23}$

1. $\mathrm{R}^{22}$ : Would you like Maung Htain Lin to speak Burmese well?

2. DKK: Ahh ... it's better if he speaks Burmese well. Then, I could teach him prayers.

3. R: Aww ... so then if he can't speak Burmese very well, for example, he doesn't have much time to learn it. If so, is it ok?

4. DKK: Yeah ... yeah

5. R: It's better if he can speak it?

6. DKK: Oh yeah. I'm going to have to teach him, but if he can't speak it, what else can I do? [laughter]

7. R: So do you think it's important for him to know Burmese?

8. DKK: Yeah, I think so ... only then I could teach him prayers.

As seen in line 8, Burmese language only acted as a catalyst for Daw Khin Kyi to help her 9year-old nephew Maung Htain Lin become a devout Buddhist. Her daily interactions with him were usually about Buddhism such as teaching him prayers as seen in the opening of the paper or explaining the meaning of the prayers to him. Most of these interactions were carried out in Burmese. Language socialization between Daw Khin Kyi and Maung Htain Lin revolved around Buddhism. Although this practice might help her maintain Burmese across generation, her 
language ideology towards Burmese as merely a mean to teach [Buddhist] prayers, as seen in Text (1), suggested a lack of reinforcement to speak Burmese within the household. Although she only spoke Burmese to Maung Htain Lin, she neither encouraged nor reinforced Maung Htain Lin to reciprocate Burmese to her. She justified teaching the prayers as teaching Burmese language to her nephew. The ambiguity of the concept $b \bar{a} t h \bar{a}$ as both religion and language led Daw Khin Kyi to synonymize teaching Burmese speaking skills, (i.e., zaga) with teaching a set of social and moral principles, (i.e., taya). Although the term $b \bar{a} t h \bar{a}$ was rarely uttered by my participants during my observation, its concept and semantic ambiguity seemed to influence their language ideologies and practices towards maintaining Burmese as a heritage language.

\section{Tell Us a Story!}

Storytelling has been a primary tool in socializing children through stories which expose them to the social and moral norms in a culture or a community. It is also a resource to socialize them to literature, the forms of language used, and other semiotic tools (Calsa, Poveda, Rujas, \& Cuevas, 2008). It is, therefore, important to pay attention to the occurrence, the setting, the role of the narrator, the purpose, and the narrative styles of storytelling in relations to the child language socialization. Burmese Buddhist children in Myanmar were socialized to Burmese literature and language through stories that are mostly extracted from Buddha's life stories or his teachings. In a monolingual Burmese speaking community back in Myanmar, the forms of language used in storytelling would significantly be Burmese, and therefore, this task achieves both language (bāthāzaga) and religious (bāthātaya) socialization. However, in a diasporic community like in Jackson Heights, Burmese immigrants have to compromise between the languages used (Burmese) and literature (Buddhist stories) in their storytelling.

I observed the storytelling, if there was, and the conversation style between Daw Hnin Si and her daughter Ma Mya Lay. Daw Hnin Si claimed the followings: she only used Burmese to talk to her 9-year-old U.S.-born daughter; she sent her daughter to monthly Buddhist lecture series for children at Daw Thuzar's; and her daughter "speaks Burmese well." During my visits, Daw Hnin Si's husband, U Myint Swe, and her elder daughter, 19-year-old Ma Moe Lay, were rarely at home. Therefore, Daw Hnin Si and Ma Moe Lay were bound to spend most of their time together alone at home. At first, I found Ma Mya Lay to be very timid and quite shy; she did not utter a single word to me while I spoke to her in Burmese although she seemed to understand my speech in Burmese. After a few days of no response from Ma Mya Lay, I tried speaking to her in English. She then whispered back to me in English as if she did not want Daw Hnin Si to hear her speaking English. Although this observation suggested that there might be a family language policy established and strictly reinforced in this family, I later found out that Ma Mya Lay was simply very shy in meeting strangers; she became quite friendly, talkative, and loud as I spent more time with her. However, when I tried to speak Burmese with her, Ma Mya Lay continued to respond to me in English regardless of her mother's presence. She sometimes codeswitched between Burmese and English intrasententially. ${ }^{24}$ I never witnessed Ma Mya Lay uttering a complete sentence or a larger phrase in Burmese rather than a lexical word. For instance, she would say the names of Burmese dishes her mother prepares, as in "Do you want to eat Mohinga (the fish paste soup) now?" Despite her claim of speaking Burmese to her daughter, Daw Hnin Si tended to exclude or ignore her daughter in her conversations with me.

In one late evening, I was playing Monopoly ${ }^{25}$ with Ma Mya Lay on the living room floor while talking to Daw Hnin Si, who was in the kitchen, preparing a dinner. Daw Hnin Si began 
reminiscing about her college life back in Yangon; she recalled the memories of skipping classes and hanging out with her friends. During her narrative, which lasted about an hour and thirty minutes, Ma Mya Lay tried to gain attention from her by commenting on Daw Hnin Si's story. However, Daw Hnin Si did not make any remark on Ma Mya Lay's comments and continued with her story. Text 2 portrays this attempt made by Ma Mya Lay while Daw Hnin Si was recollecting her college student life.

Text 2. Ma Mya Lay's attempt to divert the conversation led by Daw Hnin Si (Conversation recorded on 29 April 2016)

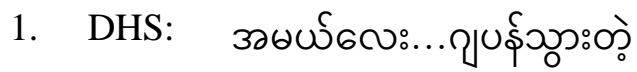 6mรर์

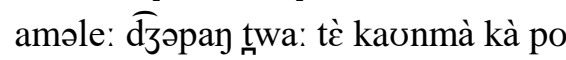 taon so: te: $\mathrm{d} \varepsilon$
2. MML: hummmmm ...

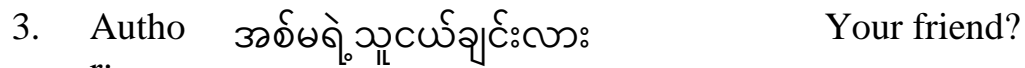

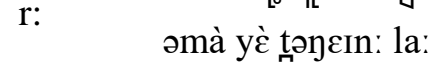

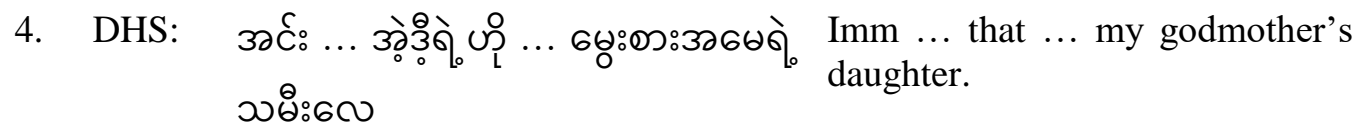
Oh my! The one who is now in Japan is worse than me.
In $\varepsilon$ dìy h ho mwaysa: əme yغ̀ təmi: le

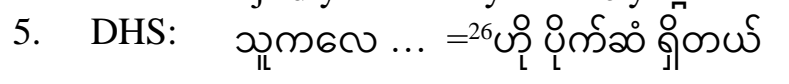 țu kā le $\quad=$ ho pasay $\int \mathrm{i} d \varepsilon$
6. MML: =I have more money
7. DHS: than my mom.

$$
\begin{aligned}
& =\mho_{\mathbb{I L}}-- \\
& =\text { tə-- }
\end{aligned}
$$
She is ... hum ... she =has money.

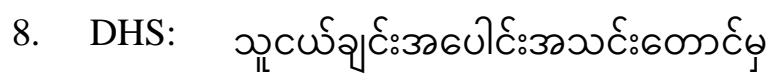

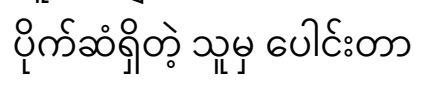

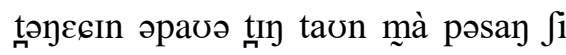
mà pav: dā

[I] only made friends with the ones who have money.

In Text 2, Ma Mya Lay attempted to bring the attention of adult interlocutors to her by asserting a different topic (her pocket money). She picked up the word pasay "money" from her mother's utterance and tried to interject a new story relating to the same topic, money. Daw Hnin Si ignored this attempt, although she heard, and continued her story. In line 5 and 6, there is a tension between Ma Mya Lay and Daw Hnin Si in turn-taking; their utterances overlapped each other in line 5, 6, and 7. It seemed as if Daw Hnin Si recognized me as the only interlocutor in this conversation while Ma Mya Lay tried to contribute to the conversation. Prior to this incident, Ma Mya Lay had made several attempts to gain attention from her mother. Since she was not given 
the floor from Daw Hnin Si, Ma Mya Lay gave up on Daw Hnin Si and tried to gain attention from me by asserting a new story, that is, her pocket money, as seen in Text 2.

Daw Hnin Si's narrative and conversational style unintentionally excluded her U.S. born daughter Ma Mya Lay. Daw Hnin Si ignored Ma Mya Lay's positive attitude to co-constructing a conversation in Burmese. Makihara's (2005a) work with Rapa Nui children highlights the importance of syncretism in speech among caretakers and children in language socialization context. Syncretic speech style, "in which two languages are mixed within two conversational interactions," can be observed in "all linguistic levels such as accents, words, grammatical phrases, and genres" (Makihara, 2005a, p.121). Syncretism can occur at a larger level, that is, across speakers in a conversation. For instance, Rapa Nui adults, who can speak both Spanish and Rapa Nui, only choose to speak in Rapa Nui to their children, and the children, who understand their caretakers' speech in Rapa Nui, decide to respond to them only in Spanish. Despite this "unreciprocal" code choice (Gal, 1979), these children continue to partake in syncretic language socialization using Rapa Nui Spanish. By "marking their Spanish with Rapa Nui" (Makihara, 2005b, p. 754), children in fact participate in constructing a role in their community. Makihara (2005b) argues that this choice does not reflect the negative attitude to speak Rapa Nui; rather it indicates their participation and expression in performing their identity as Rapa Nui. Rapa Nui adults, instead of neglecting their children's syncretic speech, recognize "its unique characteristics, its social meaning, and children's authorship" (Makihara, 2005b, p. 754) and include children's syncretism in everyday interaction. Unlike, Daw Hnin Si appeared not to be engaging in syncretic language socialization with her daughter. Ma Mya Lay's understanding of the word pəsay (money) shows her willingness to participate in the conversation. Her mother Daw Hnin Si's negligence towards this willingness prevented it from taking place.

In contrast, the communal member in Burmese Buddhist community in New York City, Daw Thuzar, seemed to employ a different speech style in engaging children and interlocutors. As mentioned in the Participants section, Daw Thuzar provided monthly Buddhist lecture series for U.S. born Burmese children; she conducted the series primarily in English but used Pali lexemes to describe the concepts in Buddhism. Daw Thuzar asserted that the parents noticed small, but significant behavioral changes in their children after a few sessions of those lectures, such as "not yelling back at their parents while they were being scolded and helping their mothers in the kitchen." According to her, not only the parents but also the children were enthusiastic about her series. By the time I met her in the fall of 2016, she had taken a break from organizing the series due to her workload as a pediatrician and her own studies to take an exam of Abhi Dhamma (ancient Buddhist texts). I was therefore unable to observe her lectures but had an interview with her. Daw Thuzar used storytelling and multivocality ${ }^{27}$ to answer my questions about her Buddhist lecture series; she set out her answers with stories in a very calm and soothing tone of voice. Text 3 portrays Daw Thuzar's narrative that was cleverly embedded in her answer to my question of how children, including Ma Mya Lay, reacted to her lectures.

Text 3. Daw Thuzar's narrative on how U.S. born Burmese children became devout to Buddhism after attending her lecture (Conversation recorded on 9 January 2017)

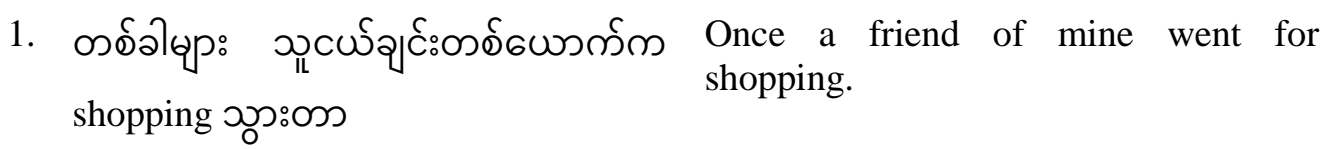




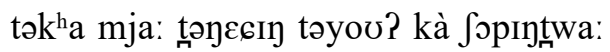

da

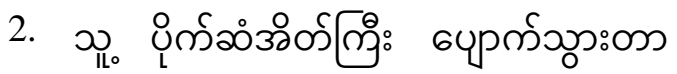
Her purse got lost!

6upरీయ్రు:60\%

tù pəsanar? dzi: pjou? twa da pjou? țwa do

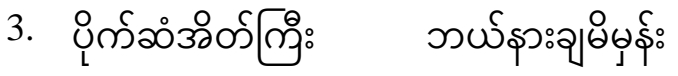

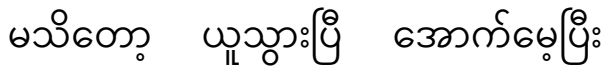

[She] didn't know where she left her purse and thought someone stole it. $O f$

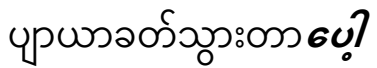

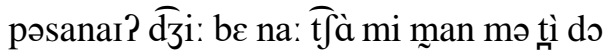
ju țwa: pi aù mè pi: pjājāân ${ }^{\mathrm{h}} \Lambda$ ?twa: tā $\boldsymbol{p} \grave{\jmath}$

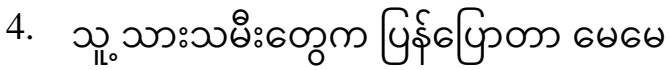

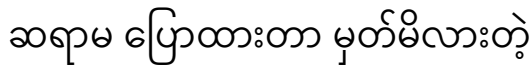

tù ța: trəmi: twe kà pjay pjaw dā meme səjamà pjawtha: dā mås?mì lā dè

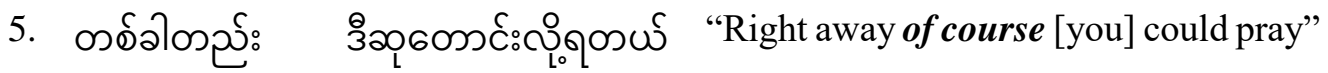
6ט७दईर्ड

tək $\mathrm{k}^{\mathrm{h}} \mathrm{d} \varepsilon$ : di sùtaひ: lò jà t $\varepsilon$ pòno

6.

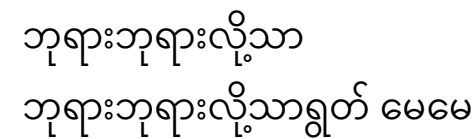

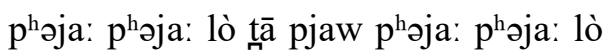
tā ywu meme

7. 2్గి గింది

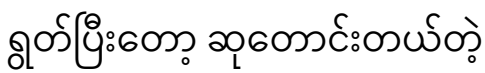

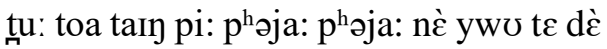
ywo pi: do sùtaひ t $\varepsilon$ dè

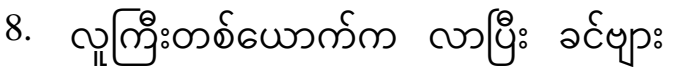

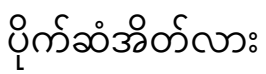

Lu đ̧̧̧i: təyơ? kà lā pi: $\mathrm{k}^{\mathrm{h} ə m j a: ~}$ pəsanai? la:

9.

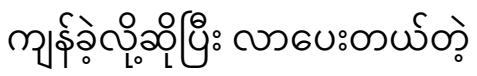

Her children told her, "Mommy, remember what teacher said?"
"Say 'Buddha, Buddha,' whisper 'Buddha, Buddha,' Mommy"
"They sat down and prayed 'Buddha, Buddha." 
sạ kè lò so pi: lā pe: te dè

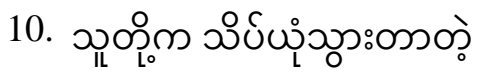

țu tò ka ter joon țwa: tā tè
"They [the children] believe in [Buddhism] so much!"

In her narrative, Daw Thuzar used Burmese pragmatic operators /pj̀/ in line 3 and 5, which is loosely translated as "of course" or "naturally" and used to emphasize the truthfulness of the story, and /no/ in line 5, which is an equivalence of the tag question "Ok?" or "alright?" to make sure the listener agrees with the utterance. "An utterance can be rendered emphatic by adding a sentence particle, such as the general emphatic [le] or [pó/bó], which expresses more insistence on the speaker" (Jenny \& Tun, 2016). Not only did the content of Daw Thuzar's story (i.e., the U.S. born children became to believe the power of Buddhist prayers), but also her use of such emphatic particles insisted that her story was sincere and reliable. The use of a dialogue between the characters through direct quotations allowed her story to be much more alive and appealing to the listener. Considering Daw Thuzar's speech style, it was unclear whether the children indeed became passionate about learning the content of Buddhism as my adult participants claimed to be, or they just simply enjoyed the act of storytelling. Due to the lack of ethnographic data from the actual lecture series, I could only contemplate ways in which Daw Thuzar's storytelling style might affect Ma Mya Lay's enjoyment in attending her lectures, which led Daw Hnin Si to claim that "her daughter speaks Burmese well."

Aside from Daw Thuzar's religious stories, Maung Htain Lin and Ma Mya Lay were not exposed to any child-directed storytelling speech in their homes. Children may be demanded to listen to the narratives between adults, whose contents may not be appropriate or relevant for the children, as seen in Text 2. Daw Hnin Si paid no attention to Ma Mya Lay's attempts to intervene. Although Daw Hnin Si initially claimed to "only speak Burmese to her daughter," my observation implied that there was a lack of socialization in Burmese with Ma Mya Lay. Daw Hnin Si did not reinforce Ma Mya Lay to speak Burmese, as well as did not recognize her daughter's attempt of syncretic speech style. Yet, the attendances at Daw Thuzar's Buddhist lecture series, that are in English, appeared to suffice for her daughter to be a Burmese in Daw Hnin Si's eyes. Daw Hnin Si emphasized on "what she exposed her daughter to," (i.e., religious teachings); however, she was unaware of "how she socialized her through," (i.e., the language practices).

\section{Conclusion: Knowing a Bāthā}

Although ways in which Burmese is being socialized in two participant-families are slightly varied by different familial styles, there is a concurring theme of generational language shift in both of their family language socialization patterns. While both adult participants in this paper agreed upon the importance of maintaining Burmese in their households and community, their understanding of religion as a precedent to language seems to complicate their practices towards maintaining Burmese as a heritage language. Their language ideologies however seemed to lubricate the process of bāthataya (knowledge of social and moral principles extracted from Buddhism) maintenance, instead of bāthāzaga (knowledge of language and literacy) maintenance. Therefore, the success of the latter itself remains in question.

In both of my participant-families, religion seemed to play an important role in the process of heritage language maintenance. At a surface level, both families expressed positive attitudes 
towards teaching Burmese to their U.S. born children and they believed that they are successfully doing so. However, from my ethnographic analysis, I observed that language ideologies adopted by my adult-participants are deeply affected by the popular Burmese term $b \bar{a} t h \bar{a}$ referring to both language and religion. The semantic and pragmatic ambiguity of this term led my adultparticipants to interchange language and religion. The first caretaker, Daw Khin Kyi, strongly synonymized the acquisition and the maintenance of Buddhism as that of Burmese language even so that she could allow her nephew to not learn Burmese if he could acquire Buddhist prayers. Buddhism became not only an important medium to pass Burmese heritage onto their U.S. born children but also an integral outlet for an ethnic minority, Bama-Chinese, like Daw Khin Kyi to "prove" her belonging to Burmese, especially Bama, heritage compared to an ethnic majority, Bama Buddhist, Daw Hnin Si. The second caretaker, Daw Hnin Si, did not seem to put as much importance on Buddhism as Daw Khin Kyi. Yet, she still shared sentiments towards the acquisition of Buddhist prayers and Buddha's life stories, that her daughter learned from Daw Thuzar's series, as a marker of being a fluent Burmese speaker. As a result, the effort to maintain bāthātaya seemed to outweigh that of bāthāzaga among the adult participants.

This synonymy of language and religion among my adult participants could of course potentially assist family language policies contributing to heritage language maintenance, yet the importance of religion did not seem to be cooperated into family language policies. Daw Hnin Si ignored her U.S. born daughter's attempt to co-construct conversation with her. They prioritized the content (bāthātaya) of their socialization and overlooked the importance of language (bāthāzaga) through which they used to carry out the socialization; children are expected to know more of Buddhist teachings than of Burmese language. Both adult participants paid a great attention to what they are socializing their children to, rather than how they are socializing them through. Although the former could compliment the latter, both families seemed to be satisfied by the achievement of the former.

Based on these findings, one could argue that "intergenerational language transmission" is bound to happen by the third generation in the Burmese Buddhist immigrant community just as Fishman (1970) theorizes. As seen with the Hmong immigrant community in Yang's (2008) study, the speakers of Burmese as a minority immigrant language face a challenge to assimilate to mainstream language for their social and economic survival. It is however worth noting that as a minority immigrant group whose linguistic status is socioeconomically non-advantageous, my participants were able to successfully compromise between assimilating to American culture and holding onto their heritage roots through other means, if not linguistically. The ambiguous concept of $b \bar{a} t h \bar{a}$ allowed them to maintain their heritage via religious socialization and at the same time pursue upward socioeconomic mobility via language socialization in English. This case study presents that heritage language maintenance across immigrant communities is not simply measurable as either "successful" or "failing." The cultural facets such as language and religion and parental conversational style that contributes to family language practices help shape immigrants' language practices. ${ }^{28}$ Sociolinguists and linguistic anthropologists must take these factors into account when examining the "success" and "failure" of heritage language maintenance across immigrant communities not just in the United States, but around the world.

While this study aspires to partake in the scholarly discussion on the topic of heritage language maintenance by offering an insight on family language socialization patterns among a recent immigrant community like Burmese, there are shortcomings due to the time constraints in my research. I was unable to ethnographically observe language socialization in larger social circles of my participants such as Maung Htain Lin with his parents, his cousins, and his peers, 
and Ma Mya Lay with her father, her sister, and her peers. Furthermore, I was also unable to conduct ethnographic fieldwork at non-familial sites that contribute to the children's Burmese acquisition and socialization. I anticipate that these gaps will invite and enthuse other scholars to explore this immigrant population. For a minority immigrant population like Bama and BamaChinese Buddhists from Myanmar in the United States, the definition of a competent Burmese, to a large extent, rests upon other cultural facets such as one's knowledge and practices of Buddhist teachings than language regardless of their positive intention to maintaining Burmese. In bilingual and multilingual communities, especially those considered to be minorities in various senses, the question therefore remains whether one of the languages can be at all replaced by other repertoires, that contour socially and culturally-defined situations in the process of becoming a competent member.

\section{Endnotes}

1. Transliteration

2. This is the loose translation or common understanding to the Pali chanting above.

3. I use pseudonyms to protect the participants' identities.

4. Refer to Participants section for more demographic information on the mentioned participants here.

5. The shelf in the house on where Buddha statue and other religious statues are put. Phaya means Buddha and sin means shelf. Phayasin is usually attached to the wall, and the highest place in the whole house. However, in this scenario, Daw Khin Kyi makes do phayasin on a small table in her tight New York City basement apartment.

6. This vignette is reconstructed from my observation while I lived with the family in 2012 prior to this study.

7. Pali is an ancient language of earliest literature in Buddhism. It is the scared language of some religious texts in Hinduism and Theravada Buddhism. It is an endangered language, and no longer spoken, but studied by religious figures such as monks.

8. 1.5 generation refers to the children who were brought to the migrated country in middle childhood, between the age of 6 to 12 (Rambaut, 2004, p. 1167).

9. 1.75 generation refers to those who arrived in the migrated country at early childhood, between the age of 0 to 5 (Rambaut, 2004, p. 1167).

10. This particular "underground" chef has moved from this apartment. She continues to make and sell Burmese dishes at her new address. However, this information is concealed to preserve her identity.

11. The name is in Pali.

12. The "underground" chefs also advertise homemade Burman or other ethnic dishes in this group. Menus change every day, and anyone interested comment under the post where and when they could come and purchase the dishes. The advertisements are usually done in Burmese language, and if one does not have Burmese font on her device, they write it in hand, take a picture of that handwritten ad, and post it in the group. Mostly the posts in this group are advertisements about homemade dishes as mentioned, however, there are posts about looking for room, ads on available room rentals and real estate, job listings such as babysitting, house-sitting, home cleaning, the couriers to and from Myanmar, announcements on Burmese food festivals at local monasteries, and so forth. 
13. "Ma /mà/" is a Burmese addressee term for young girl. After the girl gets married or after certain age, usually around 30 to 35, the addressee term changes to "Daw /do/," with which I will later refer to my older female participants.

14. The pseudonyms are used to preserve the participants' identities.

15. Here, I use the word language to refer to the Chinese "dialect" although the term "dialect" is used to refer to those languages within and outside of China. The term dialect is problematic in referring to Chinese languages, and it is used only in political context as official language - Mandarin - as a language and the rest of the languages spoken in a country as dialects. These different regional dialects are linguistically considered to be languages due to their unintelligibility among the speakers and their distinct linguistic features.

16. "Daw /do/" is a Burmese addresse term for older and middle-aged women.

17. The names are made-up, and "Khin" is not a family name, nor is "Lin." Burmans do not have first name-last name in their naming system, and each individual's name is unique and different from their parents' and siblings'. The names used for participants here are merely pseudonyms.

18. "Maung /maon/" is an equivalent addressee term of "Ma /mà/" for young boy in Burmese. For middle-aged Burmese men were addressed with the term "Ko $/ \mathrm{ko} /$," and later around the age of 40 to 45 , it changes to "U/u:/" to refer to older men.

19. Hereafter, I used past tense in discussing my participants since my findings in this paper (such as their language proficiencies, attitudes towards speaking Burmese, and their practices) are bound to change in the future.

20. The notion of "accent" is problematic; however, to gain an understanding of the children's language proficiencies in Burmese, I included this description.

21. In lower-income regions and states, even in the outskirts of Yangon, former capital city of Myanmar, there continues to be monastic education administered by Buddhist monks for local children whose parents cannot afford to send them to public schools. In addition to Buddhist teachings by the monks, these monastic schools invite volunteers (usually high school graduates from the cities) to come and teach English, and Mathematics to their students. I volunteered as a teacher at a monastic school in Thanlyin Township, a boat ride away from Yangon in 2012. I taught my students basic English language skills, Mathematics, and Burmese History.

22. $\mathrm{R}$ stands for researcher.

23. This conversation was originally in Burmese and was translated into English by the author.

24. Intrasentential codeswitching refers to the lexical codeswitching which occurs within a sentence, for instance., "My mom cooks Mohinga very well." In this example, the Burmese word, "Mohinga" (a fish-paste noodle soup) is inserted in an English utterance. In contrast, intersentential codeswitching refers to the codeswitching from a language to another language across sentences and clauses, for example, "I like cooking because

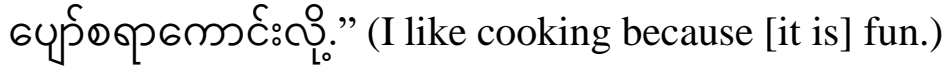

25. Monopoly is a popular American board game. The name derives from the economic concept that is used in the game, "monopoly." The game introduces the players to Henry George's economic theories such as taxation, and wealth creation.

26. Overlapped utterance from the following line. 
27. Multivocality refers to the employment of various voices of the characters or people involved in the story. Novels and literary works are the great examples of the authors' usage of multivocality.

28. See the linguistic relativity Principle by Benjamin Lee Whorf and Edward Sapir for further discussion on whether there is "traceable affinities between language and behavioral thought."

\section{References}

Baquedano-López, P., \& Garrett, P. (2002). Language socialization: Reproduction and continuity, transformation and change. Annual Review of Anthropology, 31, 339-361.

Baquedano-López, P., \& Kattan, S. (2007). Growing up in multilingual community: Insights from language socialization. In P. Auer and L. Wei (Eds.), Handbook of multilingualism and multilingual communication (pp. 69-100). Berlin, Germany: Mouton de Gruyter.

Buriel, R. (2014). Language brokers. In C. Cortés and J. Sloan (Eds.), Multicultural America: A multicultural encyclopedia (pp. 1321-1325). Thousand Oaks, CA: SAGE.

Caslsa, M. (2008). Literary voices in interaction in urban storytelling events for children. Linguistics and Education. 19, 27-55. doi:10.1016/j.linged.2007.11.001

Charney, M. (2002). Chinese in Myanmar. Encyclopedia of Modern Asia, 2, 34-35.

Crago, B. (1993). Changing patterns of language socialization in Inuit homes. Anthropology and Education Quarterly, 24(3), 205-223. doi.org/10.1525/aeq.1993.24.3.05x0966d

Duff, P. (2010). Language socialization. In N. H. Hornberger \& S. L. McKay (Eds.), Sociolinguistics and language education (pp. 427-454). Bristol, UK: Multilingual Matters.

Fishman, J. (1970). Sociolinguistics: A brief introduction. Newbury, NY: Newbury House Publisher.

Gal, S. (1979). Language shifts: Social determinants of linguistic change in bilingual Austria. New York, NY: Academic Press.

Garrett, B. (2005). What a language is good for: Language socialization, language shift, and the persistence of code-specifics genres in St. Lucia. Language in Society. 34(3), 327-361. doi: $10.1017 / \mathrm{s} 0047404505050128$

Geertz, C. (1973). The interpretation of cultures. New York, NY: Basic Books.

Giles, H., \& Johnson, P. (1987). Ethnolinguistic identity theory: A social psychological approach to language maintenance. International Journal of the Sociology of Language. 68, 256269. doi:10.1515/ijsl.1987.68.69

Irvine, J. (1989). What talk isn't cheap: Language and political economy. American Ethnologist 16, 248-267. doi:10.1525/ae.1989.16.2.02a00040

Jenny, M. (2015). Foreign influence in Burmese language. Paper presented at the International Conference on Burma/Myanmar Studies: Burma/Myanmar in Transition: Connectivity, Changes, and Challenges. Chiang Mai University, Thailand.

Jenny, M., \& Hnin, S. (2016). Burmese: A comprehensive grammar. Abingdon, UK: Routledge.

Kang, H. (2012). Korean-immigrant parents' support of their American-born children's development and maintenance of the home language. Early Childhood Education Journal. 41, 431-438. doi: 10.1007/s10643-012-0566-1 
Karamuwa, S., \& Goza, F. (2009). English acquisition and Japanese language maintenance among Japanese-American youth. International Migration. 51(5), 149-171. doi: 10.1111/j.14682345.2009.00538.x

King, A., Fogle, L., \& Logan-Terry, A. (2008). Family language policy. Language and Linguistics Compass, 2(5). 907-922. doi:10.1111/j.1749-818X.2008.00076.X

Lao, S., \& Lee, S. (2009). Heritage language maintenance and use among 1.5 generation Khmer college students. Journal of Southeast Asian American Education and Advancement. 4(1), 1-23. doi:10.7771/2153-8999.1094

Lee, S., \& Oxelson, E. (2006). "It's not my job": K-12 teachers' attitudes towards students' heritage language maintenance. Bilingual Research Journal, 30(2), 453-477. doi: 10.1080/15235882.2006.10162885

Leung, G. (2012). Contemporary Hoisan-Wa language maintenance in Northern California: Evidence from fourteen frog story narratives. International Multilingual Research Journal. 6(2), 104-120.

Makihara, M. (2005a). Being Rapa Nui, speaking Spanish. Anthropological Theory. 5(2), 117134.

Makihara, M. (2005b). Rapa Nui way of speaking Spanish: Language shift and socialization on Easter Island. Language in Society. 34(5), 727-762.

Ochs, E. (2000). Socialization. Journal of Linguistic Anthropology. 9(1), 230-233.

Ochs, E., \& Schieffelin, B. (1984). Language acquisition and socialization: Three developmental stories. In R. Shweder, \& R, LeVine (Eds.), Culture theory: Essays on mind, self, and emotion (pp. 276-320). Cambridge, UK: Cambridge University Press.

Paugh, L. (2005). Acting adults: Language socialization, shift, and ideologies in Dominica, west Indies. In J. Cohen, K. McAlister, \& J. MacSwan (Eds.), Proceedings of the $4^{\text {th }}$ international symposium on bilingualism (pp. 1807-1820). Somerville, MA: Cascadilla Press.

Rumbaut, G. (2004). Ages, life stages, and generational cohorts: Decomposing the immigrant first and second generation in the United States. International Migration Review. 38(3), 11601205.

Schieffelin, B. (1994). Code-switching and language socialization: Some probable relationships. In J. Duchan, et al. (Eds.), Pragmatics: From theory to practice (pp. 20-42). New York: NY: Prentice Hall.

Shiow-Huoy, L., \& Wiseman, L. (2000). Ethnic language maintenance among Chinese immigrant children in the United States. International Journal of Intercultural Relations. 24, 307-324.

Setsue, S. (2000). Opening a Japanese Saturday school in a small town in the United States: Community collaboration to teach Japanese as a heritage language. Bilingual Research Journal. 24(4), 465-474. doi: 10.1080/15235882.2000.10162778

Smith-Hefner, J. (1990). Language and the education of Boston-area Khmer. Anthropology \& Education Quarterly. 21(3), 250-268.

Solnit, R., \& Jelly-Scharpio. (2016). Nonstop metropolis: A New York city altas. California, CA: University of California Press.

Sridhar, K. (1988). Language shift and language maintenance among Asian Indians: Kannadigas in New York area. International Journal of Society and Language. 69, 73-87.

Yang, T. (2008). Hmong parents critical reflections on their children's heritage language maintenance. Journal of Southeast Asian American Education and Advancement, 3(17), 118. 
Zentella, C. (1997). Growing up bilingual: Puerto Rican children in New York. Malden, MA: Blackwell.

Zhang, J. (2009). Mandarin maintenance among immigrant children from the People's Republic of China: An examination of individual networks of linguistic contact. Language, Culture and Curriculum. 22(3), 195-213.

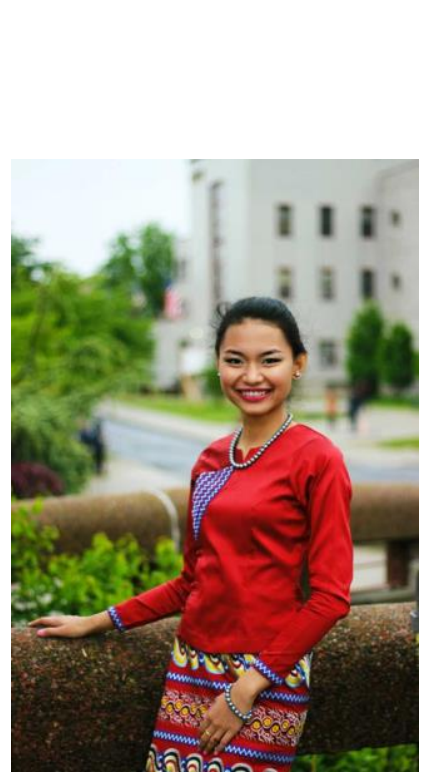

\begin{abstract}
About the Author
Chu Paing, originally from Myanmar, is currently a PhD student in the Department of Linguistics at the University of Colorado Boulder. She is affiliated with the Culture, Language, and Social Practices Program, Interdisciplinary Documentary Making Practices Program, Center for Asian Studies, and Tibet-Himalaya Initiative at CU Boulder. She completed her BA in Linguistics at Queens College, and AA in Secondary Education at LaGuardia Community College, The City University of New York. During her undergraduate studies, she conducted a year-long linguistic anthropological research study with two Buddhist Burmese immigrant families in Elmhurst, New York City. Her research interests broadly include language and power, language and law, language and identity, heritage language maintenance, and narrative. Her doctoral dissertation will explore the processes of
\end{abstract} linguistic differentiation in ethnic categorization of Myanmar. Chu is also a Graduate Student Program Director for the Literacy Practicum Program in the Department of Linguistics at CU Boulder, where she oversees and manages the partnerships between the Department and local literacy outreach organizations in the Boulder-Denver area. 


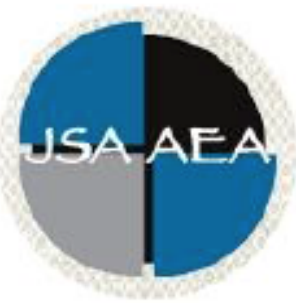

Vol.13 Iss.1 (2018)

\title{
Journal of Southeast Asian American Education and Advancement
}

\author{
www.JSAAEA.org
}

\section{Editor}

Dr. Wayne E. Wright

Purdue University

Associate Editors

Dr. Chhany Sak-Humphry

University of Hawaii at Manoa

Dr. Phitsamay Sychitkokhong Uy

University of Massachusetts, Lowell

\section{Book Review Editor \\ Dr. Vichet Chhuon}

University of Minnesota

Creative Works Editor

Bryan Thao Worra

Lao Assistance Center

\section{Journal Manager \\ Fang Gao \\ Purdue University}

\section{Editorial Review Board}

\author{
Dr. Steve Arounsack \\ California State University, Stanislaus \\ Dr. Sovicheth Boun \\ Salem State University \\ Dr. Virak Chan \\ Purdue University
}

Dr. Carl L. Bankston III

Tulane University

Dr. Phala Chea

Lowell Public Schools

Dr. George Chigas

University of Massachusetts, Lowell 


\author{
Dr. Loan Dao \\ University of Massachusetts Boston \\ Dr. Changming Duan \\ University of Missouri-Kansas City \\ Dr. Sothy Eng \\ Lehigh University \\ Dr. Vincent K. Her \\ University of Wisconsin, Eau Claire \\ Dr. Peter Nien-Chu Kiang \\ University of Massachusetts, Boston \\ Dr. Kevin K. Kumashiro \\ University of Illinois, Chicago \\ Dr. Ha Lam \\ Eastern Mennonite University \\ Dr. Jonathan H. X. Lee \\ San Francisco State University \\ Dr. Monirith Ly \\ Royal University of Phnom Penh \\ Dr. Bic Ngo \\ University of Minnesota \\ Dr. Leakhena Nou \\ California State University, Long Beach \\ Dr. Mark Pfeifer \\ SUNY Institute of Technology \\ Dr. Loan T. Phan \\ University of New Hampshire \\ Dr. Karen Quintiliani \\ California State University, Long Beach \\ Dr. Angela Reyes \\ Hunter College \\ The City University of New York \\ Dr. Fay Shin \\ California State University, Long Beach \\ Dr. Christine Su \\ College of San Mateo \\ Dr. Alisia Tran \\ Arizona State University \\ Dr. Khatharya Um \\ University of California, Berkeley \\ Dr. Kim Tran \\ University of California, Los Angeles, \\ Glendale Community College \\ Dr. Molly Wiebie \\ The University of Texas at Austin
}

Dr. Hien Duc Do

San Jose State University

Dr. Sophal Ear

Occidental College

Dr. Jeremy Hein

University of Wisconsin, Eau Claire

Dr. Nancy H. Hornberger

University of Pennsylvania

Dr. Peter Tan Keo

New York University

Dr. Yvonne Kwan

San Jose State University

Dr. Ravy Lao

California State University, Los Angeles

Dr. Stacey Lee

University of Wisconsin, Madison

Dr. Sue Needham

California State University, Dominguez Hills

Dr. Max Niedzwiecki

Daylight Consulting Group

Dr. Clara Park

California State University, Northridge

Dr. Giang Pham

University of Massachusetts Amherst

Dr. Malaphone Phommasa

University of Clifornia Santa Barbara

Dr. Kalyani Rai

University of Wisconsin-Milwaukee

Dr. Cathy J. Schlund-Vials

University of Connecticut, Storrs

Dr. Nancy J. Smith-Hefner

Boston University

Dr. Yer J. Thao

Portland State University

Dr. Monica M. Trieu

Purdue University

Dr. Silvy Un

Saint Paul Public Schools

Dr. Linda Trinh Vo

University of California, Irvine

Dr. Yang Sao Xiong

The University of Wisconsin-Madison

Dr. Zha Blong Xiong

University of Minnesota 


\section{Doctoral Student Editorial Review Board}

\author{
Linh Dang \\ University of Rochester \\ My-Lan Huynh \\ California State University East Bay \\ Hoa Nha Nguyen \\ Boston College \\ Thien-Huong Ninh \\ University of Southern California \\ Krissyvan Truong \\ Claremont Graduate University \\ Melissa Vang \\ San Diego State University \\ Claremont Graduate University \\ Anna H. Yang \\ University of Georgia
}

\author{
Annie BichLoan Duong \\ San Joaquin County Office of Education \\ Dung Minh Mao \\ University of Minnesota \\ Khoi Nguyen \\ George Mason University \\ Linda Marie Pheng \\ University of Wisconsin-Madison \\ Mai Vang \\ University of Massachusetts Boston \\ Soua Xiong \\ San Diego State University \\ Claremont Graduate University
}

